\title{
ACCEPTANCE OF PARTNER'S PRESENCE DURING LABOUR BY MIDWIVES, CLIENTS AND PARTNERS IN SELECTED HEALTH FACILITIES IN OSOGBO, NIGERIA
}

\author{
Opeyemi Afolabi ${ }^{*}$, Janet Kio², Adegboyega Afolabi \\ Comfort Ajala ${ }^{4}$, Olubukunola Ajayi ${ }^{5}$ \\ ${ }^{1}$ Department of Nursing, Adeleke University Ede, Osun State. \\ Email: afolabi.opeyemi@adelekeuniversity.edu.ng
}

${ }^{2}$ School of Nursing, Babcock University Ilishan Remo Ogun State. Email: kioj@babcock.edu.ng

${ }^{3}$ Department of Obstetrics and Gynecology, UNIOSUN Teaching Hospital, Osogbo, Osun State. Email: afolabiadegboyega@ rocketmail.com

\author{
${ }^{4}$ School of Midwifery, Lagos State University Teaching Hospital, Lagos State
}

Email: comolayo13@yahoo.com

${ }^{5}$ Oba Ademola II, School of Midwifery, Idi-Aba Abeokuta, Ogun State.

Email: bukunolayemi@gmail.com

"Corresponding Author Email: afolabi.opeyemi@adelekeuniversity.edu.ng; Tel: 08036381547

Cite this article:

Afolabi O., Kio J., Afolabi A., Ajala C., Ajayi O. (2022), Acceptance of Partner's Presence during Labour by Midwives, Clients and Partners in selected Health Facilities in Osogbo, Nigeria. African Journal of Health, Nursing and Midwifery 5(1), 15-23. DOI:

10.52589/AJHNM-

DV77KO9M

\section{Manuscript History}

Received: 7 Dec 2021

Accepted: 29 Dec 2021

Published: 6 Jan 2022

Copyright $\odot 2020$ The Author(s). This is an Open Access article distributed under the terms of

Creative Commons Attribution-

NonCommercial-NoDerivatives 4.0 International (CC BY-NC-ND

4.0 ), which permits anyone to

share, use, reproduce and

redistribute in any medium,

provided the original author and source are credited.

\begin{abstract}
This study examined the acceptance of partners' presence during labour by midwives, clients and partners in selected health facilities in Osogbo, Nigeria. Well-structured questionnaire was used to collect data from a total of 120 respondents consisting of midwives, clients and partners from the health facilities. Data collected and analyzed using descriptive and inferential statistics. The Statistics Package for Social Sciences (SPSS version 20) was employed for data analysis. All analyses were done at $p \leq 0.05$. The study reveals that there is no significant difference in the acceptance of partners' presence during labour by the three categories of respondents. The study concludes that partners ' presence be embraced as an intentional policy in health care, Midwifery training and practices in labour management in Nigeria. The study recommends that Government should initiate policies to facilitate partners' presence during labour and organize programmes on partners' presence during labour which will be made a standardized practice in all hospitals and this should be communicated and taught to staff immediately they are employed into the health care institutions.
\end{abstract}

KEYWORDS: Acceptance, Midwives, Clients, Partners, Partners Presence 


\section{INTRODUCTION}

Childbirth is the most distressing experience a woman may undergo during her lifetime (Katrijn, et al., 2017). The childbirth process follows numerous physical and emotional changes. The process evolves different feelings. These feelings necessitate the need for psychological support for women during the process. Scholars had described healthy birth experience as significant to both the baby and mother's wellbeing (Hodnett, et al., 2013). The feeling of a successful childbirth is directly linked to the help she gets during her cycle of childbirth and the support she gets throughout the process of her labour (Hodnett, et al., 2013).

According to the World Health Organization (WHO) about 830 women die globally each day as a result of pregnancy and childbirth complications that could be linked with insufficient maternal care from midwives as well as partners (WHO, 2015). Nigeria with a maternal mortality rate of 512 per 100,000 (National Population Commission (NPC) [Nigeria] \& ICF, 2019) and a patriarchal society in which pregnancy and childbirth are considered exclusively women affairs account for a significant proportion of these avoidable deaths.

The attributes of modern day treatment during childbirth are physical treatment, emotional care and clinical care. Health professionals, the woman's husband, relatives or friends can render this emotional care for the woman in labour. Childbirth provides women with physiological difficulties and the involvement of her partner during labour and childbirth is important in order to minimize distress and facilitate positive maternal outcomes. The involvement of partners during childbirth in earlier studies has been seen as advantageous and associated with positive maternal outcomes (Dlugosz, 2013). One on one labour support has been shown to be advantageous. Women who experienced continuous labour support were more likely to give birth without using analgesia or anesthesia and less likely to have cesarean or instrumental vaginal delivery, and less likely to express disappointment with their childbirth experiences (Hodnett et al., 2012).

Results from previous research conducted in more advanced countries like China and United States showed that spouse/partner help during labour and childbirth contributed to a shorter hours of labour, more favourable birth outcomes and a smoother transition into parenthood (Kainz, et al., 2010; Alden, et al., 2014). This is because the presence of non-medical individuals such as a husband (partner) provides the woman in labour with consistent nonmedical treatment.

In contrast, a partner's presence during labour is an evolving concept in Nigeria. Studies conducted on the presence and participation of partners in childbirth in low-income countries have produced conflicting results. Some studies have shown that most partners are present in India during childbirth, but low involvement was recorded in Nigeria, India and Nepal (Obi, et al., 2013 ; Iliyasu, et al., 2010; Kwambai, et al., 2013). Factors such as cultural practices, ignorance, poverty and religious belief were identified by Vehvilainen- Julkunen and Emelonye (2014) as being linked to poor partners' presence and participation during labour and childbirth. In a review of the level of partner's participation in labour between 1997 and 2013 it was documented that the presence of partners during labour differs across various regions of the world (Vehviläinen-Julkunen \& Emelonye, 2013). In another related study it was concluded that partners' presence during labour in Nigeria is very low (Vehviläinen-Julkunen $\&$ Emelonye, 2014). 
Furthermore, according to the recommendation of the World Health Organization, a woman in labour should be allowed to have a birth companion, she feels relaxed and secured in (WHO, 2016). However, in many developing countries, the recommendation of the WHO does not appear to be followed (Hodnett, Gates, Hofmeyr \& Sakala, 2012). It appears that hospital policies and aggressive attitude towards partner interference in the labour room lead to restricting partner's presence during labour and childbirth (Oluyemisi, et al., 2014). However, little had been documented about acceptability of partner's presence during labour by the midwives, clients and partners in Nigeria. Based on the foregoing, this study aimed at determining the acceptability of a partner's presence during labour by midwives, clients and partners.

\section{Methods}

This is a descriptive cross-sectional design which uses a purposive sampling technique. The research study was conducted among midwives in labour ward, antenatal, labour and postnatal units, recently delivered women and their partners at the postnatal ward of Ladoke Akintola University of Technology Teaching Hospital (LAUTECH), Osogbo and State Hospital Asubiaro Osogbo, Nigeria. Purposive sampling technique was used to recruit respondents from each of the hospitals. To be included in the study, the midwives should be practicing in any of labour, antenatal and postnatal units not less than three years. Also only women that had just delivered through cesarean section and their partner were excluded from the study.

Data was collected using a structured questionnaire which consisted of 22 items written in simple English Language and were also interpreted in Yoruba language by interviewers for easy comprehension and appropriate responses by the target respondents. The questionnaire is divided into four (4) sections. The first section asked questions about the demographic characteristics of the respondents. The second section contained 6 items and examined partners' presence contribution to positive maternal outcome. The third section of the questionnaire assessed perception to acceptance of patners' presence during labour while the last section assessed barriers to acceptance of partners' presence during labour. A graded likert scale was used to score the responses of respondents as follows: Agree $=2$; Undecided $=1$; Disagree $=0$. The face and content validity of the research instrument was validated by the researcher's supervisor while the reliability of the instrument was established in a pilot study prior to final administration for data collection and Reliability Coefficient was 0.738 .

The study protocol was approved by the Research Ethics Committee of Ladoke Akintola University of Technology Teaching Hospital, Osogbo (LTH/EC/2017/06/220). Administrative permission was sought and gained from the two hospitals where the study was carried out. Questionnaire was administered directly to the patients upon their consent to participate in the study.

Data was analyzed using a statistical package for social sciences (SPSS) version 23. Descriptive (frequency and percentages) and inferential (ANOVA) statistics were used. 


\section{RESULTS}

Demographic characteristics of the participants as shown in Table 1 revealed that the majority of the respondents were young adults aged 21-40 years. Predominantly most of the respondents had tertiary education while those with no formal education were for the clients and partners with $2.8 \%$ and $8.3 \%$ respectively. Majority of the respondents were civil servants but the highest score for unemployment goes to the clients which is $4 \%$ while that of midwives and partners were $1 \%$ and $3 \%$ respectively. Findings also revealed that majority of the respondents were Christians from the entire sample frame, followed by Islam and a few of Traditionalists.

Table 2 depicts the acceptance of midwives, clients and partners on the benefits of partners' presence during labour. That psychological physical relief is one of the benefits of a partner's presence during labour received the agreement of $86.1 \%$ of midwives, $75 \%$ of the clients and $70.8 \%$ of the partners. That partners' presence led to the encouragement for the woman in labour was supported by $91.7 \%$ of midwives, $86.1 \%$ of the clients and $79.2 \%$ of the partners. Family bonding had been supported as one of the benefits of partners' presence during labour by $70.8 \%$ of midwives; $72.2 \%$ of the clients and $81.3 \%$ of the partners. From this study, a relaxed environment was collectively embraced by $97.2 \%$ of the midwives, $58.3 \%$ of the clients and $60.4 \%$ of the partners. Also, therapeutic treatment gained general support of $80.6 \%$ of the midwives; $44.4 \%$ of the clients and $62.5 \%$ of the partners. Lastly, companionship and respect had been recognized by $94.4 \%$ of the midwives; $72.2 \%$ of the clients and $79.2 \%$ of the partners as a contributory factor to partner's presence during labour. By implication, there is no significant difference in the acceptance of partners' presence during labour by the respondents; given $\left.\left(\mathrm{F}_{2}, 119\right)=1.773, \mathrm{P}>0.05\right)$. By implication, all the respondents agreed to partners' presence during labour.

Results as presented in Table 3 shows the barriers to partners' presence during labour. For long hours of labour, $14.2 \%$ of the midwives agreed with this statement among the midwives, $19.2 \%$ of clients concurred while $23.4 \%$ affirmed the statement among the partners. Rejecting this statement include $16.8 \%$ midwives, $10.8 \%$ clients and $16.7 \%$ partners. None of the three categories respondents fell into undecided. In the case of midwives' attitude towards partners, only the clients and partners were opportune to participate and this was embraced by $17.5 \%$ clients and partners each. Responding against this statement were 9.2\% clients and $15 \%$ partners. Those who couldn't decide include 3\% clients and 7.5\% partners. . As regards poor infrastructural facilities at maternity ward, $19.22 \%$ midwives, $12.5 \%$ clients and $20.8 \%$ partners agreed while $9.2 \%$ midwives, $11.7 \%$ clients and $15 \%$ partners opposed the idea; the remaining $1.7 \%$ midwives, $5.8 \%$ clients and $4.2 \%$ partners of the respondents were undecided. Furthermore, lack of health policy on partners' presence during labour had been given support to as one of the barriers to partner's presence during labour as $20.8 \%$ midwives, $15 \%$ clients and $20.8 \%$ partners affirmed while $8.3 \%$ midwives, $12.5 \%$ clients and $7.5 \%$ partners disapproved yet $0.8 \%$ midwives, $5 \%$ clients and 7.55 partners of them remained undecided.

Table 4 presents the Univariate ANOVA showing the significant differences among the variables under study in terms of age, qualification, occupation, and religion. It could be observed that age $\mathrm{F}_{(1,115))}=.030 ; \mathrm{P}<0.05$ and occupation $\mathrm{F}_{(1,115)}=.003 ; \mathrm{P}<0.05$ showed significant difference in the acceptance of partner's presence during labour while qualification $\mathrm{F}_{(1,115)}=.482 ; \mathrm{P}>0.05$ and religion $\mathrm{F}_{(1,115)}=.217 ; \mathrm{P} 0.05$ showed no significant difference. The partial Eta squared estimated for age was 0.040 while that of occupation was 0.204 . This 
implies that age accounted for 4 percent while occupation accounted for 20.4 percent of the variance observed in the acceptance of partner's presence during labour.

\section{DISCUSSION OF FINDINGS}

The results of the study showed that the majority of the respondents agreed that the six issues (psychological/physical relief, encouragement for the woman in labour, family bonding, relaxed environment, therapeutic treatment and companionship and respect) are related to positive contributions of a partner's presence during labour. This is in tandem with study carried out by Kabakian-Khasholian, et al., (2015) that women greatly value and benefit from the presence of someone they trust (partner) during labour and childbirth which provides emotional, psychological and physical relief from the stress and discomfort associated with labour.

It was also revealed that the acceptances of the respondents (midwives, clients and partners) towards partners' presence during labour are the same. The adduced reasons to this assertion could be that knowledge in this age of information is explosive, that is majority of them have been exposed to information about the benefits of partner's presence during labour. It could be said that the presence of partners during labour is modern and divine as the world is a global village where attitude to pregnant mothers during labour is not a taboo but a way to lift up or carry the pains in labour together. To corroborate this assertion, Dick-Read (2014) was of the opinion that, partners' presence positively influences the feelings of the woman in labour and thereby gives a positive approach towards childbirth because it is believed that their presence indicates they share in their pain.

Furthermore, qualification and religion showed no significant difference in the acceptance of partners' presence during labour. It was also revealed that the following barriers can affect the presence of partners during labour which are long hours of labour, midwives attitude towards partners, poor infrastructural facility at maternity wards and lack of health policy on partners' presence during labour.

\section{CONCLUSION}

Based on findings of this study, there was no difference in the acceptance of partners' presence during labour by the midwives, clients and partners. Majority of the respondents (midwives, clients and partners) accepted partners' presence during labour and this means by implication, the acceptance partners' presence during labour by the midwives, clients and partners are the same. The study also achieved a composite contribution of age, qualification, occupation and religion on the acceptance of partners' presence during labour. Also, long hours of labour, midwives' attitude to partners, poor infrastructural facilities of the maternity wards and lack of health policy on partners' presence during labour has been found to be barriers to partners presence during labour. 


\section{RECOMMENDATIONS}

Further research is advocated in varied settings with a focus on the partners' presence involvement during childbirth in rural healthcare facilities. Comparison of the findings with partners in other settings would provide valuable information in developing policy and implementation strategies as regards partners' presence during labour.

\section{REFERENCES}

Dlugosz, S. (2013). Fathers at birth: Women's experiences of their partner's presence during childbirth. The journal of Australian Midwifery, 17(3), 20-26.

Gungor, I. \& Beji, N. K. (2017).Effects of fathers' attendance to labor and delivery on the experience of childbirth in Turkey.Western Journal of Nursing Research, 29(2), 213231.

Hodnett E. D, Gates, S, Hofmeyr, G. J, \&Sakala, C. (2013).Continuous Support for Women during childbirth. Cochrane Database of Systematic Reviews, issue 10. Art. No.: CD003766, DOI: 10.1002/14651858.CD003766.pub4. http://www.un.org/womenwatch/daw/beijing/platform/health.htm [8 December 2015]

Kainz, G., Eliasson, M. \& Von Post, I. (2010). The child's father, an important person for the mother's well-being during the childbirth: A hermeneutic study. Healthcare for Women International, 31(7), 621-635.

National Population Commission (NPC) [Nigeria], \& ICF. (2019). Nigeria Demographic Health Survey 2018. The DHS Program ICF Rockville, Maryland, USA, 748. https://dhsprogram.com/publications/publication-fr359-dhs-final-reports.cfm

Oluyemisi, A. F., Oyadiran, G. O., Ijedimma, M. O., Akinlabi, B. O. \& Adewale, A. J., (2014). Perception of pregnant women towards midwives: Attitude and practice during child delivery in health institutions in Ogbomoso, South-West, Nigeria. Epidemiology, Biostatistics and Public Health, 11(2).

Segnane, M. (2013). Mothers' expectations of midwives' care during labour in a public hospital in Gauteng. Curationis.36(1), 1-9.

UNICEF, 2015. Nigeria - The children - Maternal and child health

WHO (2016) | Nigeria Available from: www.who.int/workforcealliance/countries/nga/en/ (12 February 2016)

WHO, (2015a) Pain management for women in labour: an overview. www.who.int/maternal_child_adolescent

WHO, (2015b).Nigeria - World Health Organization. Available from: www.who.int/maternal_child_adolescent/epidemiology/.../nga.pdf (20 October 2015) 
Table 1: Demographic Characteristics of Respondents $(\mathrm{N}=120)$

\begin{tabular}{|c|c|c|c|c|}
\hline \multirow[t]{2}{*}{ Variable } & \multirow[t]{2}{*}{ Level } & \multicolumn{3}{|c|}{ Types of Respondents } \\
\hline & & $\begin{array}{l}\text { Midwives } \\
\mathrm{N}=36\end{array}$ & $\begin{array}{l}\text { Clients } \\
\mathrm{N}=36\end{array}$ & $\begin{array}{l}\text { Partners } \\
\mathrm{N}=48\end{array}$ \\
\hline \multirow{3}{*}{ Age } & $21-40$ & $22(61.1 \%)$ & $32(88.8 \%)$ & $38(79.2 \%)$ \\
\hline & $41-55$ & $12(33.3 \%)$ & $4(11.1 \%)$ & $10(20.8 \%)$ \\
\hline & 56 and above & $2(5.6 \%)$ & $0(0 \%)$ & $0(0 \%)$ \\
\hline \multirow[t]{4}{*}{ Qualification } & No formal education & $0(0 \%)$ & $1(2.8 \%)$ & $4(8.3 \%)$ \\
\hline & Primary & $0(0 \%)$ & $3(8.3 \%)$ & $0(0 \%)$ \\
\hline & Secondary & $1(2.8 \%)$ & $8(22.2 \%)$ & $12(25 \%)$ \\
\hline & Tertiary & $35(97.2 \%)$ & $24(66.7 \%)$ & $32(66.7 \%)$ \\
\hline \multirow[t]{4}{*}{ Occupation } & Unemployed & $1(2.8 \%)$ & $4(11.2 \%)$ & $3(6.2 \%)$ \\
\hline & Civil servant & $33(91.7 \%)$ & $17(47.6 \%)$ & $27(56.3 \%)$ \\
\hline & Trader & $0(0 \%)$ & $14(39.2 \%)$ & $18(37.4 \%)$ \\
\hline & Student & $2(5.6 \%)$ & $1(2.8 \%)$ & $0(0 \%)$ \\
\hline \multirow[t]{3}{*}{ Year of Experience } & Not indicated & $0(0 \%)$ & $32(89.6 \%)$ & $46(95.7 \%)$ \\
\hline & $1-20$ years & $31(86.8 \%)$ & $4(11.2 \%)$ & $2(4.2 \%)$ \\
\hline & 21 above & $5(14 \%)$ & $0(0 \%)$ & $0(0 \%)$ \\
\hline \multirow[t]{4}{*}{ Income / year } & Not indicated & $11(30.8 \%)$ & $10(28 \%)$ & $9(18.7 \%)$ \\
\hline & $\mathrm{N} 10,000.00-\mathrm{N} 500,000,00$ & $3(8.4 \%)$ & $16(44.8)$ & $16(33.3 \%)$ \\
\hline & $\$ 501,000.00-\$ 1,000,000.00$ & $9(25.2 \%)$ & $6(16.8 \%)$ & $9(18.7 \%)$ \\
\hline & Above $\mathrm{N} 1$ million & $13(36.4 \%)$ & $4(11.2 \%)$ & $14(29.1 \%)$ \\
\hline \multirow[t]{4}{*}{ Religion } & Christianity & $29(81.2 \%)$ & $21(58.8 \%)$ & $23(47.8 \%)$ \\
\hline & Islam & $6(16.8 \%)$ & $14(39.2 \%)$ & $19(39.5 \%)$ \\
\hline & Traditional & $1(2.8 \%)$ & $0(0 \%)$ & $6(12.5 \%)$ \\
\hline & Others & $0(0 \%)$ & $1(2.8 \%)$ & $0(0 \%)$ \\
\hline \multirow[t]{3}{*}{ Ethnicity } & Igbo & $3(8.4 \%)$ & $6(16.8 \%)$ & $9(18.7 \%)$ \\
\hline & Yoruba & $31(86.8 \%)$ & $30(84 \%)$ & $33(68.6 \%)$ \\
\hline & Hausa & $2(5.6 \%)$ & $0(0 \%)$ & $5(10.4 \%)$ \\
\hline
\end{tabular}

Table 2: ANOVA Showing Acceptance of Partner's Presence During Labour by the Respondents

\begin{tabular}{|l|l|l|l|l|c|}
\hline & Sum of Squares & Df & Mean Square & F & Sig. \\
\hline Between Groups & 93.557 & 2 & 46.778 & 1.773 & .174 \\
\hline Within Groups & 3086.368 & 117 & 26.379 & & \\
\hline Total & 3179.925 & 119 & & & \\
\hline
\end{tabular}


Table 3: Statistics showing barriers to partner's presence during labour $(\mathbf{N}=120)$

\begin{tabular}{|c|c|c|c|c|c|c|c|c|c|}
\hline \multirow[t]{3}{*}{ Statement } & \multicolumn{9}{|c|}{ Frequency/Percentage $(\mathrm{N}=120)$} \\
\hline & \multicolumn{3}{|c|}{ Midwives $(\mathbf{N}=36)$} & \multicolumn{3}{|c|}{ Clients $(\mathrm{N}=36)$} & \multicolumn{3}{|c|}{ Partners $(\mathrm{N}=48)$} \\
\hline & A & D & $\mathbf{U}$ & A & D & $\mathbf{U}$ & A & D & $\mathbf{U}$ \\
\hline $\begin{array}{l}\text { Long hours of } \\
\text { labour }\end{array}$ & $\begin{array}{l}17 \\
14.2 \%\end{array}$ & $\begin{array}{l}19 \\
16.8 \%\end{array}$ & $\begin{array}{l}\text { Nil } \\
0 \%\end{array}$ & $\begin{array}{l}23 \\
19.2 \%\end{array}$ & $\begin{array}{l}13 \\
10.8 \%\end{array}$ & $\begin{array}{l}\text { Nil } \\
0 \%\end{array}$ & $\begin{array}{l}28 \\
23.4 \%\end{array}$ & $\begin{array}{l}20 \\
16.7 \%\end{array}$ & $\begin{array}{l}\text { Nil } \\
0 \%\end{array}$ \\
\hline $\begin{array}{l}\text { Midwives } \\
\text { attitude towards } \\
\text { partners }\end{array}$ & - & - & - & $\begin{array}{c}21 \\
17.5 \%\end{array}$ & $\begin{array}{c}11 \\
9.2 \%\end{array}$ & $\begin{array}{l}4 \\
.3 \%\end{array}$ & $\begin{array}{c}21 \\
17.5 \%\end{array}$ & $\begin{array}{c}18 \\
15.0 \%\end{array}$ & $\begin{array}{c}9 \\
7.5 \%\end{array}$ \\
\hline $\begin{array}{l}\text { Poor } \\
\text { infrastructural } \\
\text { facilities at } \\
\text { maternity ward }\end{array}$ & $\begin{array}{c}23 \\
19.2 \%\end{array}$ & $\begin{array}{c}11 \\
9.2 \%\end{array}$ & $\begin{array}{c}2 \\
1.7 \%\end{array}$ & $\begin{array}{c}15 \\
12.5 \%\end{array}$ & $\begin{array}{c}14 \\
11.7 \%\end{array}$ & $\begin{array}{c}7 \\
5.8 \%\end{array}$ & $\begin{array}{c}25 \\
20.8 \%\end{array}$ & $\begin{array}{c}18 \\
15.0 \%\end{array}$ & $\begin{array}{c}5 \\
4.2 \%\end{array}$ \\
\hline $\begin{array}{l}\text { Lack of health } \\
\text { policy on } \\
\text { partners } \\
\text { presence during } \\
\text { labour }\end{array}$ & $\begin{array}{c}25 \\
20.8 \%\end{array}$ & $\begin{array}{c}10 \\
8.3 \%\end{array}$ & $\begin{array}{c}1 \\
0.8 \%\end{array}$ & $\begin{array}{c}18 \\
15 \%\end{array}$ & $\begin{array}{c}12 \\
12.5 \%\end{array}$ & $\begin{array}{c}6 \\
5 \%\end{array}$ & $\begin{array}{c}30 \\
20.8 \%\end{array}$ & $\begin{array}{c}9 \\
7.5 \%\end{array}$ & $\begin{array}{c}9 \\
7.5 \%\end{array}$ \\
\hline
\end{tabular}

NB $\quad A=$ Agree, $D=$ Disagree and $U=$ Undecided

Table 4: ANOVA Showing the contributions of Age, Qualification, Occupation and Religion in Predicting Partner's Presence during Labour

\begin{tabular}{|l|c|c|c|c|c|c|}
\hline Source & $\begin{array}{c}\text { Type III Sum of } \\
\text { Squares }\end{array}$ & df & $\begin{array}{c}\text { Mean } \\
\text { Square }\end{array}$ & F & Sig. & $\begin{array}{c}\text { Partial Eta } \\
\text { Squared }\end{array}$ \\
\hline $\begin{array}{l}\text { Corrected } \\
\text { Model }\end{array}$ & $2613.474^{\mathrm{a}}$ & 4 & 653.369 & 6.321 & .000 & .180 \\
\hline Intercept & 3048.233 & 1 & 3048.233 & 29.488 & .000 & .204 \\
\hline Age & 496.310 & 1 & 496.310 & 4.801 & .030 & .040 \\
\hline Qualification & 935.493 & 1 & 935.493 & 9.050 & .003 & .073 \\
\hline Occupation & 51.339 & 1 & 51.339 & .497 & .482 & .004 \\
\hline Religion & 158.998 & 1 & 158.998 & 1.538 & .217 & .013 \\
\hline Error & 11887.826 & 115 & 103.372 & & & \\
\hline Total & 500660.000 & 120 & & & & \\
\hline Corrected Total & 14501.300 & 119 & & & & \\
\hline
\end{tabular}


African Journal of Health, Nursing and Midwifery

ISSN: 2689-9418

Volume 5, Issue 1, 2022 (pp. 15-23)

www.abjournals.org

Table 4: ANOVA Showing the contributions of Age, Qualification, Occupation and Religion towards Partner's Presence during Labour

\begin{tabular}{|l|c|c|c|c|c|c|}
\hline Source & $\begin{array}{c}\text { Type III Sum of } \\
\text { Squares }\end{array}$ & df & $\begin{array}{c}\text { Mean } \\
\text { Square }\end{array}$ & F & Sig. & $\begin{array}{c}\text { Partial Eta } \\
\text { Squared }\end{array}$ \\
\hline Corrected Model & $2613.474^{\mathrm{a}}$ & 4 & 653.369 & 6.321 & .000 & .180 \\
\hline Intercept & 3048.233 & 1 & 3048.233 & 29.488 & .000 & .204 \\
\hline Age & 496.310 & 1 & 496.310 & 4.801 & .030 & .040 \\
\hline Qualification & 935.493 & 1 & 935.493 & 9.050 & .003 & .073 \\
\hline Occupation & 51.339 & 1 & 51.339 & .497 & .482 & .004 \\
\hline Religion & 158.998 & 1 & 158.998 & 1.538 & .217 & .013 \\
\hline Error & 11887.826 & 115 & 103.372 & & & \\
\hline Total & 500660.000 & 120 & & & & \\
\hline Corrected Total & 14501.300 & 119 & & & & \\
\hline
\end{tabular}

